DOI 10.4467/25439561KSR.18.015.9373

\author{
BARTŁOMIEJ BRĄŻKIEWICZ (D) https://orcid.org/0000-0003-2223-8151 \\ Uniwersytet Jagielloński \\ Kraków
}

\title{
PETERSBURG - MIASTO JAKO BOHATER LITERACKI
}

\author{
SAINT PETERSBURG - THE CITY AS A LITERARY HERO
}

\section{Streszczenie}

Petersburg - zdaniem wielu najbardziej niezwykłe i jedyne w swoim rodzaju miasto na świecie, może być postrzegane w typie bohatera na wielu poziomach. Jeden z nich odnosić się będzie do honorowego tytułu, jaki mu nadano w uznaniu heroizmu, którym wykazali się mieszkańcy miasta podczas II wojny światowej, drugi zaś do postrzegania Petersburga w kategoriach bohatera literackiego. Zgodnie z koncepcją petersburskiego tekstu literatury rosyjskiej autorstwa W. Toporowa, jedynie Petersburg zasługuje na miano miasta posiadającego własny, ucieleśniony w literaturze tekst pisany przez wielu autorów. Badania nad współczesnym wariantem tekstu petersburskiego zostały jednak przez czołowego przedstawiciela tartusko-moskiewskiej szkoły semiotyki niejako na wstępie ograniczone do dzieł literackich mających związek z miastem Petersburgiem, od kanonicznych utworów „petersburskich” A. Puszkina i N. Gogola poczynając, a uznając A. Błoka i K. Waginowa za pisarzy zamykających ten temat. Od tego czasu moglibyśmy mieć jedynie do czynienia ze zjawiskiem tzw. „tekstu leningradzkiego”. Jednakże, poddając analizie liczne przykłady składające się na „korpus petersburski” można dojść do wniosku, że teorię Toporowa należy poddać pewnej rewizji, tak aby współgrała z najnowszą rosyjską prozą. Współcześni autorzy nie tylko manifestują głęboką fascynację miastem, ale też wyrażają dlań podziw, wprost odwołują się do jego historii, eksponują sentyment do miejskich mitów, legend i tradycji, rozwijają wątki związane z jego położeniem geograficznym i towarzyszącym mu warunkom klimatycznym, dają wyraz emocjonalnemu przywiązaniu do małej ojczyzny, albo wskazują na ścisłe związki z petersburskim dziedzictwem literackim, co z kolei dowodzi niezmiennie literaturocentrycznego charakteru kultury rosyjskiej. Prezentowane studium pokazuje również, że istnieje zauważalny związek między tradycyjnie postrzeganym tekstem petersburskim a prozą najnowszą, co też może być dowodem aktualności koncepcji Toporowa.

\section{(c) (i) (ㄷ)}




\begin{abstract}
Saint Petersburg - according to many, the most amazing and the only one of its kind city in the world, can be considered as a hero on many levels. One of them concerns the honorary title "Hero City" awarded to Leningrad for the outstanding heroism of its citizens during World War II, while the second is assigned to the city perceived as a literary hero. In agreement with the concept of the Petersburg Text of Russian Literature developed by V. Toporov, Saint Petersburg exclusively deserves to be identified as the city having its own, text written by a number of authors embodied in literature. The study concerning the contemporary variant of the Petersburg Text was somehow limited by the leading representative of TartuMoscow Semiotic School himself, who basically referred to the writings relating to the city of Saint Petersburg, starting with the images depicted in literary-canonical texts by A. Pushkin and N. Gogol and recognizing A. Blok and K. Vaginov as the topic-closing writers. Since then it could only be seen as the so-called "Leningrad Text" phenomenon. However, analyzing a number of exemplars constituting the entire Petersburg literary corpus, one could come to the conclusion that Toporov's theories need to be reviewed in order to be consistent with contemporary Russian prose. Consequently, present-day authors not only demonstrate their deep attraction and admiration of Saint Petersburg, but also openly refer to its history, expand the environmental topics, uncover the emotional attachment to their homeland, expose their interest to urban myths, legends and traditions, or display solid relations to Petersburg literature heritage, which absolutely proves that Russian culture is constantly the literature-centered one. The study also shows that a noticeable relation to the traditional Petersburg Text can be observed in many of the latest works of prose which, again, proves the infiniteness of the entire concept.
\end{abstract}

Słowa kluczowe: Petersburg, petersburski tekst literatury rosyjskiej, literatura rosyjska Keywords: Saint Petersburg, Petersburg Text of Russian Literature, Russian Literature

Forma pisanego małymi literami wyrażenia „miasto bohater” - komunikuje jasno: chodzi o miasto Petersburg postrzegane w typie bohatera, jedynie fragmentarycznie w kategorii bohaterstwa czy heroizmu. Zagadnienie to, na pewno nie wprost i nie jednoznacznie, ma odniesienie do tytułu, którym 1 maja 1945 r., głównie za okazane podczas blokady 1941-1944 męstwo, wyróżniono Leningrad. Termin ten, pisany wielkimi literami - „Miasto Bohater” - w swej wymowie jest precyzyjny, konkretny, wąski, ale też - jego zakres wpisuje się w treść „Petersburga - miasta bohatera" - w znaczeniu szerokim, zapisywanego małymi literami.

Miasto bohater - bohater miasto Petersburg - to w szczególności bohater literacki. W powszechnej opinii miasto niezwykłe, jedyne w swoim rodzaju, w którym najznamienitsi rosyjscy pisarze widzieli aurę tajemniczości, odnajdywali skrywane 
za jego zagadkowym charakterem bogactwo znaczeń, zauważali niewythumaczalność zachodzących w nim zdarzeń ${ }^{1}$.

Nawiązania do pełnego tajemnic, mrocznego i strasznego grodu, w rzeczonym ujęciu w literaturze rosyjskiej pojawiają się na przełomie lat 20. i 30. XIX w., głównie za sprawą Aleksandra Puszkina, jego Jeźdźca miedzianego (Медный всадник), Damy pikowej (Пиковая дама) oraz powstałych w przywołanym okresie wierszom². Dzięki pracom Władimira Toporowa natomiast, zyskają one miano petersburskiego tekstu literatury rosyjskiej.

Rozumiany jako jednorodny, spójny tematycznie cykl utworów literackich rozwijających motyw Petersburga, a przede wszystkim wpływu, jaki specyficzna atmosfera miasta ma na indywidualne i zbiorowe dzieje jego mieszkańców, petersburski tekst literatury rosyjskiej kieruje nas w stronę tzw. tekstu kultury, w ujęciu tartusko-moskiewskiej szkoły semiotyki pojęcia różniącego się od lingwistycznej koncepcji tekstu. Za tekst uznaje się tu bowiem dowolny system znaków, który posiada „umiejętność" przekazywania znaczenia, i w którym jednocześnie skrywa się, jest zakodowana pewnego rodzaju pamięć kulturowa ${ }^{3}$. Zdaniem semiotyków, kultura, której istota polega na przekazie informacji, na interakcji - w końcu - na komunikacji ${ }^{4}-$ stanowi konglomerat tekstów. Tekstów literackich, muzycznych, architektonicznych, teologicznych, a nawet - prawnych. Wszystkie one niosą w sobie pewien kod, przekazują odpowiednią treść. Wynika z tego, że tekstem miejskim - albo tekstem miasta, w tym również tekstem petersburskim - będzie powstały w określonych ramach czasowych oraz w granicach właściwej danej zbiorowości semiosfery, spójny system znaków, symboli, mitów i wyobrażeń na temat miasta, czytelny i zrozumiały dla konkretnej populacji, i zawierający szczegółowy bagaż znaczeń (sensów) ${ }^{5}$.

Jak twierdzi Toporow, Petersburg ma swój własny ,język”. Przemawia do nas przez swoje ulice, place, wody, wyspy, ogrody, budynki, pomniki, ludzi, historię, idee i może być rozumiany jako swego rodzaju heterogeniczny tekst, któremu przypisuje się pewien wspólny sens i na podstawie którego można zrekonstruować określony system znaków, urzeczywistniany w tekście ${ }^{6}$. Obok obrazów samego miasta,

${ }^{1}$ Zob. В. Малышев, Петербургские тайны. Занимательный исторический путеводитель, Санкт-Петербург, Союз писателей Петербурга, 2017, ss. 5-7.

${ }^{2}$ Zob. B.Н. Топоров, Петербургский текст русской литературы, Санкт-Петербург, Искусство-СПБ, 2003, s. 22.

${ }^{3}$ Zob. A. Piatigorski, J. Łotman, Tekst i funkcja, tłum. J. Faryno, [w:] Semiotyka kultury, wybór i oprac. E. Janus i M.R. Mayenowa, przedm. S. Żółkiewski, Warszawa, Państwowy Instytut Wydawniczy, 1975, s. 101.

${ }^{4}$ Zob. B. Żyłko, Semiotyka kultury, Gdańsk, słowo/obraz terytoria, 2009, s. 101.

${ }^{5}$ Ibidem.

${ }^{6}$ Zob. B.Н. Топоров, Петербургский текст..., op.cit., s. 22. 
które raz jest piękne, zachwyca swoim przepychem, bogactwem i jest symbolem postępu, a innym razem jawi się jako gród posępny, złowieszczy, depresyjnie oddziałujący na swych mieszkańców, charakterystyczne dlań będą opisy typowego dla północnej stolicy klimatu, zjawisk atmosferycznych związanych z wodą, obecność bagien i rozlewisk, mgły, ciężkiego powietrza trącącego zgnilizną, częstych podtopień i powodzi ${ }^{7}$.

Fiodor Dostojewski, odwołując się do atmosfery miasta, pisał w Młodziku (Пoдросток):

„W taki petersburski, zgniły, wilgotny i mglisty poranek dzikie marzenia jakiegoś puszkinowskiego Hermana z „Pikowej damy” (świetna postać, niezwykły, zupełnie petersburski typ - typ z petersburskiego okresu!) - muszą moim zdaniem jeszcze się wzmocnić. Sto razy wśród tej mgły nasuwała mi się dziwaczna, lecz natrętna myśl: „A cóż, kiedy rozwieje się ta mgła i pójdzie w górę, czy nie zniknie wraz z nią całe to zgniłe, wilgotne miasto, czy nie podniesie się wraz z mgła, nie zginie jak dym, a pozostanie tylko dawne fińskie mokradło, a pośród niego, może dla ozdoby, spiżowy jeździec na ciężko dyszącym, zgonionym koniu?” Jednym słowem nie mogę wyrazić swoich wrażeń, bo to wszystko fantazja, wreszcie poezja, a zatem - bzdura [...]”»

Podobne wyobrażenia, w połączeniu z tematami związanymi z rozwojem miasta, które określano nawet mianem Nekropolii ${ }^{9}$, zwracając uwagę zarówno na ogromną liczbę osób, które poniosły śmierć przy jego budowie, jak i na niezwykle wysoki odsetek zgonów wśród mieszkańców w okresie późniejszym, dają obraz dość przygnębiający ${ }^{10}$. Dymitr Mereżkowski w eseju z 1908 r. zatytułowanym Petersburg opustoszeje (Петербургу быть пусту) określa nawet Petersburg mianem ,gigantycznego grobu, wypełnionego ludzkimi kośćmi”11. Pisarz dodaje też: „И кажется иногда в желтом тумане, что мертвецы встают и говорят нам, живым: «Вы нынче умрете!»"12 - niczym powtórzenie kierowanych pod adresem nowej stolicy słów zgubnej przepowiedni, które wypowiedzieć miała Jewdokia Łopuchina, pierwsza żona Piotra Wielkiego ${ }^{13}$.

Innym, w sposób niebagatelny determinującym zachowanie mieszkańców miasta czynnikiem był jego specyficzny, funkcjonalny charakter. Petersburg to w założeniu

${ }^{7}$ Ibidem, s. 26.

${ }^{8}$ F. Dostojewski, Młodzik, thum. J. Polecki, Białystok, Instytut Wydawniczy Kreator, 2002, s. 134.

${ }^{9}$ Zob. B.Н. Топоров, Петербургский текст..., ор.cit., s. 30.

${ }^{10}$ Ibidem, s. 31

${ }^{11}$ Zob. Д.С. Мережковский, Петербургу быть пусту, [w:] http://az.lib.ru/m/merezhkowskij_d_s/text_0200.shtml [dostęp: 27.05.2018].

${ }^{12}$ Ibidem.

${ }^{13}$ Е. Лукин, Пространство русского духа, Санкт-Петербург, Союз художников, 2007, s. 10. 
stolica, centrum administracyjne i sztab dowodzenia armią, a więc miasto zamieszkiwane w znacznej mierze przez urzędników państwowych i wojskowych, których nade wszystko cechował pęd do kariery. Powie przecież samobójca Swidrygajłow:

„Rzadko które miasto ma tyle ponurych, ostrych i dziwnych wpływów na duszę ludzką co Petersburg. Już sam klimat ile znaczy! A przecież jest to centrum administracyjne całej Rosji i charakter tego miasta musi wpływać na wszystko"14.

W dalszej kolejności zauważyć należy, że Petersburg, podobnie jak inne ważne miasta, ma swoje mity, w szczególności alegoryzujący mit o założeniu miasta oraz o jego stwórcy ${ }^{15}$. Mit o „stworzeniu” Petersburga został następnie jakby podjęty przez mit o jego demiurgu, który pojawia się z jednej strony jako genius loci, a z drugiej, jako postać, która nie wyczerpała swej życiowej energii i która ukazuje się w ważnych dla miasta chwilach jego mieszkańcom, pojawia się jako głos losu, jako symbol jedynego $\mathrm{w}$ swoim rodzaju miasta $\mathrm{w}$ rosyjskiej historii ${ }^{16}$. Bojaźni i trwodze względem osoby założyciela Petersburga, ustami wpatrującego się w spiżowy pomnik bohatera Jeźdźca miedzianego, dawał wyraz Aleksander Puszkin, pisząc:

„Straszliwy jest, wpatrzony w mrok!

Jaka zaduma! Co za wzrok!

Jaka potęga w nim ukryta!

$[\ldots]$

O, władco losów wszechmogący!

Czyż nie tak samo twoja dłoń,

Wzniesiona nad otchłanią pusta,

Szarpnęła Rosję twardą uzdą,

Że dęba wspięła się jak koń?”'17.

Lecz aurę tę wyczuwali nie tylko Rosjanie. Dziadów części III Ustęp zawiera wersy, które stały się bezpośrednią inspiracją do napisania Jeźdźca miedzianego ${ }^{18}$. Adam Mickiewicz odnosi się w nich do rodowodu stolicy oraz petersburskiego kolorytu:

${ }^{14}$ F. Dostojewski, Zbrodnia i kara. Powiesśc w sześciu częściach z epilogiem, thum. J.P. Zajączkowski, Warszawa, Prószyński i S-ka, 2008, s. 502.

${ }^{15}$ Zob. B.Н. Топоров, Петербургский текст ..., ор.cit., s. 22.

${ }^{16}$ Ibidem, s. 23.

${ }^{17}$ A. Puszkin, Jeździec Miedziany. Opowieść petersburska, [w:] Lutnia Puszkina. Utwory Aleksandra Puszkina wybrat i przetlumaczyt Julian Tuwim, Wrocław, Zakład Narodowy im. Ossolińskich Wydawnictwo, 2009, s. 162.

${ }^{18}$ Zob. B. Galster, Mickiewicz i Puszkin, [w:] Mickiewicz - Puszkin. Materiaty źródłowe i bibliograficzne. Antologia, zebr. i oprac. J. Świdziński, wstępem opatrzył B. Galster, tom I, Mickiewicz o Puszkinie, Poznań, Wydawnictwo Poznańskiego Towarzystwa Przyjaciół Nauk, 1991, s. 14. 
„Tu grunt nie daje owoców ni chleba,

Wiatry przynoszą tylko śnieg i słoty;

Tu zbyt gorące lub zbyt zimne nieba,

Srogie i zmienne jak humor despoty!

Nie chcieli ludzie; - błotne okolice

Car upodobał, i stawić rozkazał,

Nie miasto ludziom, lecz sobie stolicę:

Car tu wszechmocność woli swej pokazał. -

W głąb ciekłych piasków i błotnych zatopów

Rozkazał wpędzić sto tysięcy palów

I wdeptać ciała stu tysięcy chłopów"19.

Niemniej, w tekście petersburskim zgodność opisów miasta z realiami nie ogranicza się wyłącznie do zasygnalizowania uwarunkowań klimatycznych, topograficznych, krajobrazowych i społeczno-kulturowych. Aby tekst stał się rzeczywisty powinien być uzupełniony o inne, głębsze treści, które w większym jeszcze stopniu niż wyżej wymienione struktury określają sposób zachowania jego mieszkańców - czyli o to, co niematerialne, lecz odczuwalne. Napisze wszak Konstanty Waginow w rozpoczynającym się od słów Om берегов на берег... wierszu z 1926 roku:

„В стране Гипербореев

Есть остров Петербург"го.

Mityczna, legendarna, wolna od chorób i cierpień, utopijna kraina wiecznej szczęśliwości, beztroski i łagodnego klimatu ${ }^{21}$ - to bezapelacyjnie wyidealizowany, celowo kontrastujący z rzeczywistym, wymarzony, wyśniony, stanowiący wycinek alternatywnej rzeczywistości obraz miasta, jakim w obliczu fałszywej racjonalności nowego ustroju podmiot liryczny pragnie je widzieć, jeszcze nie „oberiucki” absurdyzm, który w odniesieniu do Petersburga w pełni ujawni się w nieukończonej Harpagoniadzie (Гарпагониада).

Można zgodzić się z tym lub nie, lecz według naszkicowanej przez Toporowa koncepcji, jedynie Petersburg zasługuje na miano miasta posiadającego własny, ucieleśniony w literaturze tekst i jest prawdopodobnie jedynym miastem, którego tekst był i będzie pisany przez wielu autorów ${ }^{22}$. Badania nad współczesnym warian-

${ }^{19}$ A. Mickiewicz, Dziadów części III Ustęp, [w:] idem, Dziady. Część III, posł. i przypisy J. Wieczerska-Zabłocka, Wrocław, Zakład Narodowy im. Ossolińskich - Wydawnictwo, 1984, s. 180.

${ }^{20}$ К. К. Вагинов, Стихотворения и поэмы, Директ-Медиа, Москва 2014, ss. 140-141.

${ }^{21}$ Zob. hasło: Hyperborejczycy, thum. J. Sachse, [w:] P. Grimal, Stownik mitologii greckiej i rzymskiej, Wrocław, Zakład Narodowy im. Ossolińskich - Wydawnictwo, 1990, s. 150.

${ }^{22}$ Zob. B. Н. Топоров, Петербургский текст ..., ор.cit., s. 26. 
tem tekstu petersburskiego zostały niejako ograniczone przez samego Toporowa, który zasadniczo odwoływał się do utworów mających związek z Petersburgiem, uznając Annę Achmatową, Osipa Mandelsztama, Aleksandra Błoka i Konstantina Waginowa za pisarzy zamykających ten temat ${ }^{23}$. Niektórzy, idący w ślad za ustaleniami Toporowa, a przez to samoograniczający się w zakresie dalszych dociekań, badacze twierdzą, że od tego czasu moglibyśmy mieć jedynie do czynienia z tzw. „tekstem leningradzkim”, postrzeganym bądź jako rozdział w dziejach tekstu petersburskiego, bądź jako oddzielne zjawisko ${ }^{24}$.

A przecież wątki związane $\mathrm{z}$ leningradzkim okresem dziejów Petersburga, nie mniej ciekawe i pojemne znaczeniowo, ściśle wiążą się z tekstem petersburskim. Dość stwierdzić, że w samym mieście, szczególnie do połowy lat 40. XX wieku, poza dokonanym w 1924 r. chrztem nazewniczym, niewiele się zmieniło. We wspomnianej przed momentem Harpagoniadzie, w dialogu dwóch starszych pań Waginow owszem (w polskim thumaczeniu niuans ten jest nieuchwytny, w przypisie przytaczam fragment oryginału), przeciwstawi sobie Petersburg i Leningrad:

„Starsza kobieta pierwsza:

- Pięknieje nasze miasto. Jaką wziąć ulicę, każda kwitnie.

Starsza kobieta druga:

- Jak dla mnie, Leningrad jest apatyczny. Jest w nim jakaś urażona niewinność”25.

Ale też poczyni następującą obserwację:

„Pomyśleć tylko - powiedział Anfiertjew - że śródmieście niemal się nie zmieniło od lat siedemdziesiątych zeszłego wieku. Gdyby przyjechała do Leningradu jakaś staruszencja,

${ }^{23}$ Ibidem, ss. 24-25.

${ }^{24}$ Zob. В. Тюпа, Коренная мифологема Петербургского текста, [w:] Существует ли Петербургский текст?, red. В.М. Маркович, В. Шмид, Санкт-Петербург, Издательство Санкт-Петербургского университета, 2005, ss. 81-91; Е.Н. Жаднова, Современные подходы к изучению проблемы петербургского текста, „Известия Саратовского университета. Новая серия. Серия Филология. Журналистика”, 2013, t. 13, wyd. 4, ss. 70-73; Д.Ю. Кондакова, Понятие «петербургский текст» в современной научной рецепщии, „Вісник Харківського національного університету ім. В.Н. Каразіна", 2011, nr 936, wyd. 61, ss. 276-280.

${ }^{25} \mathrm{~K}$. Waginow, Harpagoniada, tłum. i posłowiem opatrzył A. Pomorski, Warszawa, Czytelnik, 2001, ss. 160-161. Cytowany dialog w języku rosyjskim brzmi:

„1-я пожилая женщина:

- Питер-то наш приукрашается. Любая улица, возьмите, вся в цвету.

2-я пожилая женщина:

- Ленинград мне апатичен. Какая-то в нем укоризненная чистота" (wyróżnienia tekstu - B.B.).

К.К. Вагинов, Гарпагониада, [w:] http://az.lib.ru/w/waginow_k_k/text_0040.shtml [dostęp: 21.05.2018]. 
która nie odwiedzała go od lat siedemdziesiątych XIX wieku, nawet by nie zauważyła, że w świecie zaszły wielkie zmiany"26.

Można zapytać, czy zauważyłaby wcześniejsząjeszcze, mającą miejsce w 1914 r., zmianę nazwy miasta, z niemiecko brzmiącej, na jej rosyjskie tłumaczenie Piotrogród, skoro w świadomości społecznej, jak twierdzą badacze, od samego początku jego istnienia i mimo oficjalnych reform nazewniczych, miasto wciąz $-\mathrm{w}$ tym również przez cały okres radziecki - pieszczotliwie nazywano Pitrem ${ }^{27}$ ? Kolejny dowód na to, że toponimy są przekaźnikiem kultury, nośnikiem pamięci, odbiciem historii, swoistym lustrem, w którym pobłyskują refleksy świadomości społecznej ludności zamieszkującej określoną przestrzeń ${ }^{28}$.

Tym samym można się zastanawiać, czy na przykład powstałe w tragicznym okresie blokady Leningradu utwory, albo późniejsze relacje, wspomnienia i dzienniki ten okres obejmujące, jak choćby Kronika Oblężenia (dziennik blokady) (Ocadнaя Запись (блокадный дневник) $)^{29}$ autorstwa uznanego orientalisty, profesora Aleksandra Bołdyriewa, wspomnienia Dymitra Lichaczowa zatytułowane $W$ oblężonym Leningradzie (В блокадном Ленинграде) $)^{30}$, albo Jarzmo dzieciństwa czasów bloka$d y$ ( $В$ плену у блокадного детства $)^{31}$ - autobiograficzna powieść napisana przez inną, ceniona petersburską pedagog, profesor kulturologii Tamarę Teterska, nie mają związku z tekstem petersburskim? Wymienione utwory, podobnie jak dziesiątki innych, od Wiery Inbier i Olgi Bergholc począwszy, a na Księdze blokady (Блокадная книга) ${ }^{32}$ Alesia Adamowicza i Daniiła Granina skończywszy, nie zawsze muszą być uznawane za arcydzieła literatury - często oszczędne w formie, w stylu zaś surowe, niekiedy niedopracowane, są jednak świadectwem historii konkretnego miejsca oraz związanych z nim ludzi, dla których miasto było całym ich życiem i na których dzieje Petersburga odcisnęły dożywotnie piętno.

W analogiczny sposób, w życie ówczesnego, jak i późniejszych pokoleń, wpisuje się i po dzień dzisiejszy kształtuje mentalność mieszkańców Petersburga dobrze

${ }^{26}$ K. Waginow, Harpagoniada ..., op.cit., ss. 175-176.

${ }^{27}$ Zob. Топонимы Санкт-Петербурга, [w:] Больщая Топонимическая Энииклопедия Санкт-Петербурга, red. А.Г. Владимирович, Санкт-Петербург, Информационно-издательское агенство «ЛИК», 2013, s. 46.

${ }^{28}$ Zob. M. Czerwiński, Archiwum znaków - semiotyka pamięci kulturowej, „Tekst i dyskurs - Text Und Diskurs", 2014, nr 7, s. 33.

29 А.Н. Болдырев, Осадная запись (блокадный дневник), Санкт-Петербург, Европейский Дом, 1998.

${ }^{30}$ Д.С. Лихачев, В блокадном Ленинграде, Москва, Алгоритм, 2017.

${ }^{31}$ Т.Н. Тетерская, В плену у блокадного детства. Петербургский роман, Санкт-Петербург, Издательство Союза Писателей Санкт-Петербурга, 2013.

${ }^{32}$ A. Adamowicz, D. Granin, Księga blokady, tłum. W. Bieńkowska, Warszawa, Państwowy Instytut Wydawniczy, 1988. 
znany, na kilku domach zachowany i konsekwentnie odnawiany, niewątpliwie stanowiący składową pejzażu miasta napis - „Obywatele! Podczas ostrzału artyleryjskiego ta strona ulicy jest najbardziej niebezpieczna” („Граждане! При артобстреле эта сторона улицы наиболее опасна"). Mało kto jednak brnie w dociekania, dlaczego akurat strony północne i północno-wschodnie ulic były najbardziej narażone na ostrzał artyleryjski, skoro miasto oblężone było ze wszystkich stron. Powszechnie wiadomo, że niemiecki ostrzał prowadzony był z rejonu Wzgórz Pułkowskich i Strielnej a także, że Finowie, mimo faktycznie trwającej w latach 1941-1944 tzw. wojny kontynuacyjnej (Finlandia - ZSRR), odmówili brania w nim udziału, że głównodowodzący fińskimi wojskami Carl Gustaw Mannerheim nie zgodził się udzielić sojusznikowi (Trzeciej Rzeszy) wsparcia. Fakt ten thumaczy się sentymentem, jaki przyszły prezydent Finlandii żywił do Petersburga. W mieście, które uważał za najpiękniejsze na świecie mieszkał, kształcił się, odbywał służbę wojskową i zawarł związek małżeński z Rosjanką ${ }^{33}$. Wiadomo też o jego nieskrywanej miłości do rosyjskiej kultury i sympatii do byłego władcy, Mikołaja II, który obdarzył go przyjaźnią. Przejawem serdecznej relacji była fotografia $\mathrm{z}$ autografem cara, która do końca życia Mannerheima stała na jego biurku ${ }^{34}$.

Dzieje Petersburga okazują się zatem wielkim hipertekstem, niezależnie od miejsca, w którym zaczniemy go „czytać”, poznawać - odkryjemy wielopoziomową sieć połączeń, układającą się w czytelną, utrwaloną w postaci nieskończonej liczby komunikatów, kulturową całość.

Abstrahując jednak od kwestii skończoności czy nieskończoności tekstu petersburskiego, wciąż aktualny i w twórczości współczesnych autorów widoczny jest problem relacji, $\mathrm{w}$ jakiej najnowsza proza petersburska pozostaje względem tradycji - czyli rdzenia tekstu petersburskiego. Wypada w tym miejscu zgodzić się z formułowanym przez rosyjskich literaturoznawców założeniem, zgodnie z którym pod pojęciem współczesnej prozy petersburskiej rozumieć należy teksty różnych petersburskich autorów powstające w ostatniej dekadzie XX w. aż po czasy obecne. W utworach tych dostrzec można zarówno wyraźny związek z tradycyjnym tekstem petersburskim, jak i odniesienia do petersburskiej teraźniejszości - w podobnym sensie, w jakim kanon ów przedstawiał Toporow.

Spośród wielu współczesnych publikacji, utworów jednego autora czy zbiorów różnych twórców, które wyzyskują odniesienia do tradycyjnego tekstu petersburskiego, warto wspomnieć popularną na zachodzie Europy i w USA serię wzbogaconą o dwa tomy, których bohaterami są rosyjskie stolice: Moskwa Noir (Moscow Noir) ${ }^{35}$

\footnotetext{
${ }^{33}$ Zob. В. Малышев, Петербургские тайны ..., op.cit., ss. 224-225.

${ }^{34}$ Ibidem.

${ }^{35}$ Moskwa Noir, red. J. Goumen, N. Smirnowa, thum. E. Skórska, Warszawa, Claroscuro, 2011.
} 
i Petersburg Noir (St. Petersburg Noir) ${ }^{36}$. Do wydanego w 2013 roku w Rosji tomu petersburskiego, redakcyjnemu tandemowi Julia Smirnowa i Natalia Goumen udało się zaprosić zarówno wziętych i uznanych autorów - Siergieja Nosowa, Antona Czyża czy Pawła Krusanowa, jak i pisarzy mniej znanych, niszowych. Tom, który rozpoczyna Wstęp zatytułowany Czternaście odcieni czerni na celu ma zrobić użytek z drzemiącego w tytułowym mieście mrocznego potencjału i ciemną jego stronę uchwycić w estetyce noir. Czternaście opowiadań rzeczywiście cechuje próba oddania mrocznej atmosfery miasta, utrwalonej w rzuconych na karty klasycznej literatury rosyjskiej zagadkowych i przerażających niekiedy obrazach. Petersburg Noir ukazuje zarówno miasto-symbol nowoczesności, jak i centrum przedziwnych zdarzeń, niecodziennych zjawisk, dla których tło stanowią epizody z historii miasta, fakty z życia osób z nim związanych oraz elementy miejskiego folkloru. Świat bandytów, środowisko prostytutek, ludzi bezdomnych i narkomanów, kraina skorumpowanych urzędników jako petersburska codzienność - to wszystko składowe otaczającej mieszkańców rzeczywistości, niejednokrotnie determinujące ich postępowanie, swoista przestrzeń kulturowa Petersburga ${ }^{37}$. Ten zbiór złożonych z symboli tekstów, zgodnie z koncepcją Jurija Łotmana, z jednej strony jako nośnik pamięci kulturowej zawiera w sobie informację o kontekstach historycznych, z drugiej zaś ożywa w kontekstach wciąż nowych, współczesnych ${ }^{38}$. Konteksty te, jak powie z kolei Clifford Geertz, należy odczytać, przeanalizować i poddać interpretacji, by, odkrywając ich znaczenie, zbliżyć się do koncepcji konkretnej kultury ${ }^{39}$ i rozwikłując pojęciowe światy zaproponować interpretacyjne ich wyjaśnienie ${ }^{40}$. Jak słusznie zauważyła Katarzyna Duda, charakterystyczną cechą wielu utworów literackich, szczególnie tych powstałych w przestrzeni literaturocentrycznej kultury rosyjskiej, jest to, że stają się one „,...] zaledwie pretekstem/pre-tekstem do szukania, już poza nim, lecz niemożliwym bez niego, kontekstów szerszych, sensów ukrytych w złożoności ludzkiej egzystencji”" ${ }^{41}$. Chociaż estetycznie nierówne, wybrane przez Smirnową i Goumen opowiadania,

${ }^{36}$ Petersburg Noir, red. J. Goumen, N. Smirnowa, tłum. G. Szymczak, Warszawa, Claroscuro, 2015.

${ }^{37}$ Zob. E. Przybył-Sadowska, J. Sadowski, D. Urbanek, Rosja. Przestrzeń, czas i znaki, Kraków, Wydawnictwo Libron - Filip Lohner, 2016, s. 14.

${ }^{38}$ Zob. J. Łotman, Uniwersum umystu. Semiotyczna teoria kultury, przekł. i przedm. B. Żyłko, Wydawnictwo Uniwersytetu Gdańskiego, Gdańsk 2008, s. 183; J. Łotman, Pamięć kultury, [w:] idem, Kultura, historia, literatura, wybór, tłum. i wstęp B. Żyłko, Gdańsk, Wydawnictwo Uniwersytetu Gdańskiego, 2017, s. 138.

${ }^{39}$ Zob. C. Geertz, Interpretacja kultur. Wybrane eseje, tłum. M.M. Piechaczek, Kraków, Wydawnictwo Uniwersytetu Jagiellońskiego, 2005, s. 19.

${ }^{40}$ Zob. C. Geertz, Wiedza lokalna. Dalsze eseje z zakresu antropologii interpretatywnej, thum. D. Wolska, Kraków, Wydawnictwo Uniwersytetu Jagiellońskiego, 2005, s. 31.

${ }^{41}$ K. Duda, Szkice o prozie rosyjskiej XXI wieku. Ulicka, Szyszkin, Pielewin, Minajew, Sienczyn, Kuricyn, Starobiniec..., Kraków, Księgarnia Akademicka, 2017, s. 10. 
z całą pewnością interesujące, wielokrotnie zabawne oraz ironiczne, mają swój urok i, w gruncie rzeczy, mogą być klasyfikowane w kategoriach tekstu petersburskiego. Nie wyczerpują jednak tkwiącego w tekście miasta potencjału i zbyt często trąca podobieństwem do rosyjskiej czernuchy ${ }^{42}$.

Autorem, który swą twórczą energię kanalizuje w utworach sięgających do oryginalnych motywów, osadzając je w idei tekstu petersburskiego, co daje impuls do ponownej refleksji nad jego geneza, zadumy nad jego istota, jest Siergiej Arno. Prozaik, czerpiąc z elementów składających się na substrat tekstu petersburskiego, z jednej strony tworzy kolejną jego kulturową i literacką warstwę, harmonizującą z utrwalonymi w literaturoznawczej tradycji założeniami autorstwa Toporowa, z drugiej zaś wpisuje się w nową jego odsłonę, jako szczególnego nurtu literatury rosyjskiej przełomu wieków XX i XXI. Pisarz, nawiązując do kanonu tekstu petersburskiego - Puszkina, Gogola i Dostojewskiego - w którym odnajduje elementy fantastyki, swoisty romantyzm, ale i znaczną dozę groteski i absurdu, w jednym z wywiadów krótko odniósł się do własnego stylu:

„[...] о Петербурге-Ленинграде нельзя писать иначе - уж слишком это странный город" ${ }^{43}$.

Wbrew zauważalnej skłonności autorów przełomu wieków XX i XXI do dekonstrukcji utrwalonych mitów, Arno dąży do rozbioru mitu Petersburga nie po to jednak, by zakwestionować głęboko osadzone w świadomości społecznej znaczenia, lecz po to, by uwypuklić jego źródło oraz przedstawić własną jego interpretację. Dla pisarza mit ów wyrasta z opisywanych przezeń historii, będących źródłem kolejnych, typowych dla petersburskiego folkloru legend, podań i mitów - od fascynacji Piotra I dziełem Frederika Ruyscha i narodzinach Kunstkamery ${ }^{44}$, przez bytujące w pierwszym rosyjskim muzeum monstra, legendy o newskich rusałkach ${ }^{45}$, podania

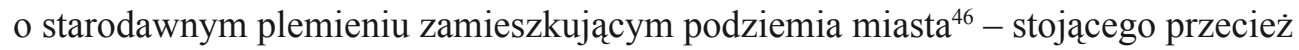
na miejscu przedchrześcijańskich cmentarzysk, opowieści o duchach i widziadłach,

\footnotetext{
${ }^{42} \mathrm{Na}$ temat czernuchy zob. С. Чупринин, Русская литература сегодня. Жизнь по понятиям, Москва, Время, 2007, ss. 755-756.

${ }^{43}$ В. Владимирский, Сергей Арно: «Во всей нашей жсизи мало здравого смыссла», „Питерbook” 29.12.2012 (czasopismo „Питерbook” ukazywało się w formie papierowej w latach 19952005, realia rynku wymusiły na autorach ograniczenie działalności do publikacji elektronicznej), [w:] http://krupaspb.ru/piterbook/fanclub/pb_fan_column.html?nn=155\&ord=5\&sb=\&np=1 [dostęp: 27.05.2018].

${ }^{44}$ С. Арно, Фредерик Рюйш и его дети, Санкт-Петербург, Союз Писателей Санкт-Петербурга, 2012.

${ }^{45}$ С. Арно, Истории петербургских утопленнии, Санкт-Петербург, Издательство «Метропресс», 2015.

${ }^{46}$ С. Арно, Живодерня, Санкт-Петербург, Издательство «Северо-Запад», 2005.
} 
po aniołów, pod kopułą Soboru świętego Izaaka Dalmatyńskiego debatujących na temat kulturalnej przyszłości Rosji ${ }^{47}$. Arno patrzy na petersburski krajobraz niczym na tekst kultury, dowodząc na literackiej płaszczyźnie twierdzenia Łotmana, że:

„Kultura jako całość może być rozpatrywana jako tekst. Należy jednak z całą mocą podkreślić, iż jest to niezwykle złożony tekst, rozpadający się na hierarchię 'tekstów w tekście' i tworzący skomplikowane sploty tekstów"48.

Tym sposobem w prozie Arno, poświadczającej istnienie kontekstualnych związków najnowszej twórczości literackiej z ich ideowo-estetycznym pierwowzorem, odnajdziemy odniesienia zarówno do tradycji, jak i współczesności oraz do wszystkich składników petersburskiej mentalności.

Szersze omówienie twórczości Arno prezentowałem w innych artykułach ${ }^{49}$, pominę również analizę opowiadań ze zbioru Petersburg Noir, by skupić się na treści innego, niezwykle interesującego tomu, wydanego wiosną 2017 r., a zatytułowanego W Pitrze żyć. Od Pałacowego do Sadowej, od Ganguckiej do Szpalernej. Osobiste historie (В Питере жить. От Двориовой до Садовой, от Гангутской до Шиалерной. Личные истории $)^{50}$, który powstał dzięki pomysłowi Natalii Sokołowskiej i Jeleny Szubinej.

Jest to pozycja o tyle ciekawa, że zupełnie inna od pozostałych, współcześnie ogrywających motyw Petersburga, a więc wpisujących się w krąg petersburskiego tekstu literatury rosyjskiej. Redaktorki, które wprost sygnalizują chęć nawiązania do tradycji tekstu petersburskiego, do udziału w tym przedsięwzięciu zaprosiły grupe

${ }^{47}$ С. Арно, Смирительная рубашка для гениев. Роман-бред, Санкт-Петербург, Издательство Союза Писателей Санкт-Петербурга, 2012.

48 J. Łotman, Kultura i eksplozja, tłum. i słowem wstępnym opatrzył B. Żyłko, Warszawa, Państwowy Instytut Wydawniczy, 1999, ss. 118-119.

${ }^{49}$ Zob. B. Brążkiewicz, Ku tajemnicy życia wiecznego. Piotr I i Frederik Ruysch w historyczno-fantastycznej powieści S. Arno „, Фредерик Рюйш и его детu”, [w:] Sacrum świata wschodniego $i$ zachodniego w kulturze stowiańszczyzny. Musica Antiqua Europae Orientalis XVII, Acta Slavica, Bydgoszcz, Filharmonia Pomorska im. Ignacego Paderewskiego w Bydgoszczy, 2014, ss. 441-449; B. Brążkiewicz, ,Idioci rządza światem”. Między fantastykq a realizmem - „Powieść o miłości, ale też o idiotach i topielicach... ” Siergieja Arny, „Colloquia Litteraria Sedlcensia”, 2014, t. XIV-II, ss. 19-26; B. Brążkiewicz, Mroczny Petersburg. Proza Siergieja Arno, [w:] Światło i ciemność w literaturze, kulturze i sztuce: od antyku do współczesności, red. D. Szymonik, E. Kozak, A. Pogoda-Kołodziejak, Siedlce, Instytut Neofilologii i Badań Interdyscyplinarnych Uniwersytet Przyrodniczo-Humanistyczny w Siedlcach, Instytut Kultury Regionalnej i Badań Interdyscyplinarnych im. Franciszka Karpińskiego. Stowarzyszenie, 2015, ss. 103-111; B. Brążkiewicz, Uprawdopodobnienie fikcji w powieści Siergieja Arno „Smiritel'naya rubashka dlya geniyev”, „Conversatoria Litteraria”, 2016, r. X, ss. 263-274; B. Brążkiewicz, ,Смирительная рубашка для гениев” Сергея Арно или вопрос о литературном кризисе, „Kultura Słowian. Rocznik Komisji Kultury Słowian PAU”, 2017, t. XIII, ss. 235-244.

${ }^{50}$ В Питере жить. От Двориовой до Садовой, от Гангутской до Шпалерной. Личные истории, zebrały Н. Соколовская, Е. Шубина, Москва, Издательство АСТ, 2017. 
trzydziestu pięciu autorów, przedstawicieli świata literatury, sztuk plastycznych, teatru, kina, prasy, nauki..., by z szerszym gronem odbiorców, czytelników podzielili się swoimi osobistymi wrażeniami, przeżyciami, przemyśleniami - związanymi z zamieszkiwaniem w północnej stolicy, by spróbowali przekazać choć po części cechy petersburskiego sposobu myślenia, mentalności, miejskiego klimatu. Trzeba powiedzieć, że autorzy perfekcyjnie poradzili sobie z tym zadaniem, odnosząc się do meandrów miejskiego życia dzisiaj i w przeszłości w sposób barwny i z prawdziwym zaangażowaniem, a nade wszystko, relacjonując osobiste historie.

W tomie napotkamy cały szereg odniesień do rosyjskiej tradycji literackiej, do korpusu petersburskiego tekstu, co dowodzić będzie nie tylko głębokiego zakorzenienia współczesnych mieszkańców miasta w rosyjskiej kulturze, lecz również świadomego jej odczytywania. Przykładowo, Dmitrij Bykow w tekście zatytułowanym Wyspa Jełagina (Елагин Остров) pisze:

„Как всякий неурожениец города, я связан с ним не столько биографически или географически, сколько литературно..." ${ }^{51}$.

Znany polskim czytelnikom autor powieści Czerwony Syjon $\left(\right.$ Красный Сион) ${ }^{52}$, Aleksandr Mielichow, rozpoczyna znajdujący się w antologii tekst pod tytułem Może pozostańmy barbarzyńcami? (Как бы нам остаться варварами?) оd słów:

„Архитекторы лишь закладывают семена городов, а взращивают их поэты: чего бы стоил Петербург без „Медного всадника”!”53.

Wspomniany przy okazji tomu Petersburg Noir Paweł Krusanow z kolei napisze:

„Общее место: старый Петербург - прибежище болотных чертей; теней Пушкина, Гоголя, Достоевского, Белого..." ${ }^{54}$.

Natomiast we wspomnieniu W Pitrze-żyć! (B Пumepe-жumb!), od którego tytuł wziął też cały zbiór, a który jest parafrazą dobrze znanej strofy pochodzącej z przeboju grupy „Leningrad” W Pitrze - pić (B Пumepe - numb) ${ }^{55}$, i która, wraz z podobizną jej autora - Siergieja „Sznura” Sznurowa, współcześnie stała się motywem obecnym na wielu gadżetach nieoficjalnie promujących miasto, Jelizawieta Bojarska dzieli się z czytelnikiem następującym spostrzeżeniem:

${ }^{51}$ Д. Быков, Елагин Остров, [w:] В Питере жить..., ор.cit., s. 192.

${ }^{52}$ A. Mielichow, Czerwony Syjon, thum. N. Woroszylska, Warszawa, Wydawnictwo Sic!, 2007.

${ }_{53}$ А. Мелихов, Как бы нам остаться варварами?, [w:] В Питере жить..., op.cit., s. 157.

${ }^{54}$ П. Крусанов, Центр новый, незатопляемый, [w:] В Питере жить..., ор.cit., s. 448.

${ }^{55}$ Redaktorki tomu nawiązują doń expressis verbis, wykorzystując jako motto otwierające publikację. Zob. В Питере жить..., op.cit., s. 9. 
„Естественным образом мой Петербург „менял окраску”. Вдруг становился фатальным и мистическим - после прочтения „Пиковой дамы”... властным, самодержавным и беспомощным перед стихией и перед той же властью - после „Медного всадника” [...]. Все то же было с Гоголем и, конечно же, с Достоевским. Я открыла для себя новый, мрачный, удушливый, зловонный мир [...]. [...] мир серости, тумана, духоты, грязи, нищеты, дна, низа [...]. Потом [...] для меня возникли Петербург Ахматовой, Мандельштама, Блока, Бродского, Довлатова, и так далее, и так далее" 56 .

Widzimy więc, po pierwsze, miasto, którego dzieje przeplatają się z historią literacką, w sposób ewidentny określającą specyficzny charakter Petersburga. Po drugie, samo przywoływanie w tekstach autorów almanachu wątków historycznych, nawiązywanie do czasów minionych, świadczy bezspornie o konstytutywnym ich oddziaływaniu na świadomość mieszkańców, czemu wyraz dała Tatiana Tołstoj, pisząc w zatytułowanym Cudze sny (Чужие сны) tekście:

„Петербург строился не для нас. Не для меня. Мы все там чужие: и мужчины, и женщины $[\ldots]^{\prime 5}$.

Albo Nikita Jelisiejew, który ironicznie odnosząc się do kilkukrotnej zmiany nazwy miasta, skonstatował:

„Петербург - Петроград - Ленинград - Петербург... (собаке трижды кличку сменить - с ума сойдет, а мы - ничего, привыкли)..."58.

Znakomity Walerij Popow natomiast, uchodzący za uosobienie współczesnego petersburskiego literata, we wspomnianym kontekście podzielił się taką oto, ironiczną obserwacją:

„Но все равно - город воспитывает людей. В Москве - толпа, а у нас - променад. И как приятно - выйти с Московского вокзала и пойти не спеша по Невскому. Дойдешь до Дворцовой, вдохнешь воздух с Невы - и любой стресс проходит!"

Jak przystało na tom, zgodnie z zamysłem projektodawczyń nawiązujący do tekstu petersburskiego, wcale niemało w nim odniesień do geograficznego położenia miasta i warunków klimatycznych. Wspomniany wyżej Nikita Jelisiejew wyraża następującą opinię:

\footnotetext{
${ }^{56}$ Е. Боярская, В Питере - жить!, [w:] В Питере жить..., op.cit., ss. 474-475.

${ }^{57}$ T. Толстая, Чужие сны, [w:] В Питере жить..., op.cit., s. 11.

${ }^{58}$ Н. Елисеев, Разорванный портрет, [w:] В Питере жить ..., ор.cit., s. 21.

${ }^{59}$ В. Попов, Мои места, [w:] В Питере жить..., op.cit., s. 365.
} 
„Когда море вторгается в русскую петербургскую литературу? Когда и как оно появляется? Правильно. В самом знаменитом знаковом петербургском тексте, в „Медном всаднике” Пушкина. Море - убийца. Море - угроза. Море - опасная, страшная стихия $[\ldots]]^{\prime 60}$.

Od czasów Puszkina zaś Rosjanie, jakby uwarunkowani obrazem spustoszonego przez złowrogi żywioł miasta, zdaniem Jelisiejewa oddalają się od bliskiego Petersburgowi morza, nie czynią z Bałtyku literackiego bohatera, odgradzają się od niego - w przeciwieństwie do mórz południowych krańców Rosji.

Tatiana Tołstoj zaś, dzieli się z czytelnikiem dość zawiłym pragnieniem:

„Я непременно куплю в Питере квартиру: я не хочу простой человеческой жизни. Я хочу сложных снов, а они в Питере сами родятся из морского ветра и сырости" ${ }^{\prime \prime}$.

Pisarka w tym miejscu nie tylko podkreśla pozytywne konsekwencje świadomie przeżytych trudności. Dzieli się również przeświadczeniem, że przekleństwo może stać się inspiracją, czynnikiem mobilizującym człowieka do działania, natchnieniem dla twórcy.

Osobną kategorię odniesień stanowią w tomie liczne nawiązania do leningradzkiego okresu dziejów miasta. Mimo postrzegania go przez pryzmat całościowo ujmowanej historii, w której przecież dominują wątki związane z osobą fundatora Wenecji Północy, w poszczególnych tekstach daje się wskazać fragmenty nawiązujące do postaci wodza rewolucji. Aleksandr Gorodnicki, występując poniekąd w kontrze do spopularyzowanego przez Władimira Bukowskiego, a odnoszącego się do losu dzieci w Związku Radzieckim sformułowania: „[... [ i jeśli pierwszymi słowami, których się nauczy, będą MAMA i TATA, to potem już obowiązkowo LENIN"62, radziecki i rosyjski bard, podobnie jak dysydent-emigrant reprezentujący pokolenie lat sześćdziesiątych, przywołując obrazy z własnego dzieciństwa oświadcza:

„Я называю себя ленинградцем, ибо „Ленинград” было третьим словом после слов „папа” и „мама”, которые я услышал в жизни. А про „дедушку Ленина” и все его замечательные качества узнал значительно позднее"бз.

Natomiast Irina Basowa, w zatytułowanych Powrót (Возвращение) wspomnieniach, podkreśla:

\footnotetext{
${ }^{60}$ Н. Елисеев, Разорванный портрет, [w:] В Питере жить..., ор.cit., s. 38.

${ }^{61}$ Т. Толстая, Чужие сны, [w:] В Питере жить ..., op.cit., s. 13.

${ }^{62}$ W. Bukowski, I powraca wiatr..., thum. A. Mietkowski, Gdynia, Petit, 1990, s. 41.

${ }^{63}$ А. Городницкий, Василевский остров, [w:] В Питере жсить..., ор.cit., s. 135.
} 
„Ленинград. Всякий раз - приезжаю ли я сюда, вспоминаю ли о нем - как рефреном звучит „Я вернулся в мой город, знакомый до слез...” И тут же контрапунктом трезвая мысль - мой город, но до слез незнакомый... Мой, но незнакомый”64.

Basowa, urodzona w domu nr 9 przy Nabrzeżu Kanału Gribojedowa (w tzw. „,nadbudówce dla pisarzy”), córka rozstrzelanego w 1938 roku na fali wielkiej czystki poety Borisa Korniłowa, zdradza, że nie potrafi odnosić się do rodzinnego miasta inaczej, jak nazywając je Leningradem. To jakby kontynuacja rodzinnych paradoksów związanych z okresem radzieckim - ojciec, najpierw mocno zaangażowany w działalność propagandowo-agitacyjną, zaliczany do pokolenia poetów komsomolskich, ginie oskarżony o trockizm ${ }^{65}$; Basowa, z niewiadomego powodu wciąż wraca do miasta, w którym faktycznie nigdy nie mieszkała na stałe - została ewakuowana podczas blokady, studiowała w Moskwie, w końcu wyemigrowała do Paryża - i niezamierzenie definiuje je w kategoriach radzieckich. Osobliwości refleksji Basowej dodaje też widoczne w przywołanym cytacie nawiązanie do wiersza Osipa Mandelsztama zatytułowanego Leningrad (Ленинград), w którym podmiot liryczny zwraca się jednak do miasta „Petersburgu!"

Ciekawe są także podkreślające nadzwyczajny, niepowtarzalny charakter miasta obserwacje, jak choćby stwierdzenie autorstwa Denisa Kotowa:

$$
\text { „Петербург - удивительное пространство" }{ }^{67} \text {. }
$$

Albo passusy akcentujące integracyjny, a zarazem mitopoetycki ${ }^{68}$ charakter miejskiej przestrzeni, którą tworzą zamieszkujący ją ludzie. Przez nieschematyczne ujęcie, inne od właściwego tradycyjnemu tekstowi petersburskiemu, zdehumanizowanego obrazu miasta, dodają mu one cech pozytywnych. Magda Aleksiejewa we wspomnieniu Petersburgu, ja nie chcę umierać, nie czas, jeszcze przecież mój numer telefonu znasz... (Петербург, я ещуе не хочу умирать, у меня телефонов твоих номера... $)^{69}$ pisze:

${ }^{64}$ И. Басова, Возвращение, [w:] В Питере жить..., ор.cit., s. 329.

${ }^{65}$ Zob. P. Fast, Realizm socjalistyczny, [w:] Historia literatury rosyjskiej XX wieku, red. A. Drawicz, Warszawa, Wydawnictwo Naukowe PWN, 2002, s. 367.

${ }^{66}$ Zob. О.Э. Мандельштам, Сочинения в двух томах, t. 1: Стихотворения. Переводы, zebrała П.М. Нерлера, Художественная литература, Москва 1990, s. 168; thum. na j. polski S. Barańczak, zob. O. Mandelsztam, Poezje, oprac. i wstęp R. Przybylski, Warszawa, Państwowy Instytut Wydawniczy, 1971, s. 122.

${ }^{67}$ Д. Котов, Моя подьяческая история, [w:] В Питере жить ..., ор.cit., s. 233.

${ }^{68}$ Zob. W. Toporow, Przestrzeń i tekst, [w:] idem, Przestrzeń i rzecz, thum. B. Żyłko, Kraków, Universitas, 2003, ss. 17-20.

${ }^{69}$ Tytuł jest cytatem z wiersza Mandelsztama Leningrad. W polskiej wersji przytaczam fragment w thumaczeniu Barańczaka. Zob. przypis 66. 
„Но города - это не только улицы и дома. Это прежде всего люди. [...] И - мои города. Москва и Петербург. Они, как люди, помагают жить в этом сложном мире $[\ldots]^{\prime \prime 70}$.

W podobnym duchu wypowiada się Daniił Kociubiński:

„У меня нет любимых петербургских мест. Как нет „любимых мест” в себе самом. Город - это я, и это то, что меня очаровало и обмануло"71.

Dalej autor podkreśla, że z jego przywiązaniem do Petersburga, uczuciowym stosunkiem do miasta, nie była w stanie wygrać nawet namawiająca go na przeprowadzkę do Moskwy ukochana:

„Девушка сказала мне: „Что ты ждешь от Петербурга? Он уже все, что мог, сказал и сделал. «Цивилизация на пенсии». Оставь его в покое. Поехали лучше в Москву!" Я не поехал. И она не поехала"72.

Para oczywiście rozstała się ...

Z kolei Jelena Kolina zauważa:

„И все мы в Питере связаны, перепутаны, передружены [...]. Думаю, без Питера чувствуешь себя голым, ну, может быть, не совсем голым, но без шапочки"73.

Za wypowiedź semantycznie najpełniejszą uznać jednak można zakończenie wspomnianego już tekstu autorstwa Jelizawiety Bojarskiej:

„Мне нравится, что у меня есть Ленинград моего детства [...]; есть мой Петроград и блокадный Ленинград - история моей семьи [...]; есть мой воображаемый Петербург, есть места для грусти, есть для радости [...]. Есть даже самый любимый и ни с чем не сравнимый запах каналов. Но я уверена, что такой калейдоскоп любовей и привязанностей есть у каждого петербуржца.

Так что в Питере - пить, в Питере - любить, в Питере - жить!'74.

Ukazując miasto wielopłaszczyznowo, odnosząc się do historycznych i kulturowych zawiłości Północnej Stolicy, a jednocześnie akcentując osobisty, emocjonalny doń stosunek, autorka ryzykuje wyrażenie uogólniającego sądu na temat swoistego charakteru Petersburga. Mimo wszystko, trudno się z nim nie zgodzić.

${ }^{70}$ М. Алексеева, „Петербург, я еще не хочу умирать, у меня телефонов твоих номера... ”, [w:] В Питере жить ..., ор.cit., s. 285.

${ }^{71}$ Д. Коцюбинский, Вечность вместо жизни, [w:] В Питере жить..., op.cit., s. 241.

${ }^{72}$ Ibidem, s. 247.

${ }^{73}$ Е. Колина, „Это Питер, детка”, [w:] В Питере жить ..., op.cit., s. 101.

${ }^{74}$ Е. Боярская, В Питере - жить!, [w:] В Питере жить ..., op.cit., s. 476. 
Temat Petersburga pojawiającego się jako miasto bohater utworów literackich trudno wyczerpać. Do dnia dzisiejszego występuje on w kontekście utrwalonych w rosyjskiej klasyce literackiej obrazów Puszkina, Gogola, Dostojewskiego i innych. Absolutnie nie stanowią one balastu dla współczesnych twórców, prędzej istotny punkt odniesienia do kulturowej spuścizny „małej ojczyzny”. Wciąż ważne pozostają nawiązania do okresu leningradzkiego - nie tylko czasów blokady, ale też lat dzieciństwa dzisiejszego „średniego" pokolenia autorów. Istotnymi są również kwestie widoczne przede wszystkim w utworach najnowszych, uwypuklające, mające absolutnie pozytywny wydźwięk obserwacje, dotyczące łączących mieszkańców więzi wspólnotowych, zażyłości, bliskości duchowej oraz innych elementów tożsamościowych grupy, o czym świadczą nie tylko przywołane wyżej utwory, lecz również te, które na bieżąco pojawiają się w prasie literackiej o zasięgu ogólnorosyjskim $^{75}$, w czasopismach petersburskich ${ }^{76}$, jako oddzielne publikacje książkowe ${ }^{77}$ czy zbiory tekstów wielu autorów ${ }^{78}$. I właśnie ta ostatnia kategoria posiada nieprzeciętną wartość poznawczą, skupiając w jednym miejscu rozmaite formy, treści i punkty widzenia, pozwala nie tylko objąć dość szerokie spektrum obrazu miasta bohatera, ale też zakosztować odrobiny miejskiego kolorytu Petersburga.

${ }^{75} \mathrm{~W}$ dziedzinie prozy przykładowo: П. Алексеев, Глаголь жсли, „Литературная газета”, 16-22 мая 2018, nr 19 (6643), s. 21.

${ }^{76}$ Wśród wciąż pojawiających się wspomnień z okresu blokady Leningradu: А. Башмакова, Дневник Хельги Лухан (урожденной Хайншаймер), „Аврора”, 2018, nr 2, ss. 25-52.

${ }^{77} \mathrm{Na}$ przykład proza młodej petersburskiej autorki: А. Обух, Дикий янтарь. Рассказы, Санкт-Петербург, Издательство „Арт-Экспресс”, 2018.

${ }^{78}$ Już w chwili złożenia do druku niniejszego artykułu drukarnię opuściła pierwsza transza kolejnego zbioru wielu autorów zatytułowanego 315. Рассказы писателей Санкт-Петербурга, którego promocja miała miejsce podczas XIII Petersburskich Międzynarodowych Targów Książki (XIII Санкт-Петербургский Международный Книжный Салон), a który jeszcze nie trafił na księgarskie półki. Na wydany staraniem Związku Pisarzy Sankt-Petersburga i nakładem wydawnictwa „Petropolis” tom, pod redakcją Suzanny Kuleszowej i Kiry Groznej, składa się 59 małych form prozatorskich autorstwa 28 petersburskich twórców literatury, między innymi wymienionych wyżej - Siergieja Arno, Aleksandra Mielichowa, Walerija Popowa, Pawła Aleksiejewa, ale też Swietłany Mosowej, Lwa Naumowa czy Iriny Dudinej, a pretekstem do jego powstania, jak wskazuje tytuł, okazała się być chęć uhonorowania 315 urodzin miasta. Zob. 315. Рассказы писателей Санкт-Петербурга, состав. сборника С. Кулешова и К. Грозная, Союз писателей Санкт-Петербурга / Издательский дом „Петрополис”, Санкт-Петербург 2018. 


\section{Literatura}

Adamowicz A., Granin D., Księga blokady, tłum. W. Bieńkowska, Warszawa, Państwowy Instytut Wydawniczy, 1988, 534 ss.

Brążkiewicz B., ,, Idioci rzqdzq światem”. Między fantastykq a realizmem - „Powieść o miłości, ale téz o idiotach i topielicach... ” Siergieja Arny, „Colloquia Litteraria Sedlcensia", 2014, t. XIV-II, ss. 19-26.

Brążkiewicz B., Ku tajemnicy życia wiecznego. Piotr I i Frederik Ruysch $w$ historyczno-fantastycznej powieści S. Arno „, Фредерик Рюйш и его дети”, [w:] Sacrum świata wschodniego i zachodniego w kulturze słowiańszczyzny. Musica Antiqua Europae Orientalis XVII, Acta Slavica, Bydgoszcz, Filharmonia Pomorska im. Ignacego Paderewskiego w Bydgoszczy, 2014, ss. 441-449.

Brążkiewicz B., Mroczny Petersburg. Proza Siergieja Arno, [w:] Światto i ciemność w literaturze, kulturze i sztuce: od antyku do współczesności, red. D. Szymonik, E. Kozak, A. Pogoda-Kołodziejak, Instytut Neofilologii i Badań Interdyscyplinarnych Uniwersytet Przyrodniczo-Humanistyczny w Siedlcach, Siedlce, Instytut Kultury Regionalnej i Badań Interdyscyplinarnych im. Franciszka Karpińskiego. Stowarzyszenie, 2015, ss. 103-111.

BrążkiewiczB., Uprawdopodobnieniefikcji wpowieści Siergieja Arno ,, Smiritel'naya rubashka dlya geniyev”, „Conversatoria Litteraria”, 2016, r. X, ss. 263-274.

Brążkiewicz B., , Смирительная рубашка для гениев” Сергея Арно или вопрос о литературном кризисе, „Kultura Słowian. Rocznik Komisji Kultury Słowian PAU”, 2017, Tom XIII, ss. 235-244.

Bukowski W., I powraca wiatr..., thum. A. Mietkowski, Gdynia, Petit, 1990, 316 ss.

Czerwiński M., Archiwum znaków - semiotyka pamięci kulturowej, „Tekst i dyskurs - Text Und Diskurs", 2014, nr 7, ss. 31-48.

Dostojewski F., Młodzik, tłum. J. Polecki, Białystok, Instytut Wydawniczy Kreator, 2002, 557 ss.

Dostojewski F., Zbrodnia i kara. Powieść w sześciu częściach z epilogiem, tłum.

J.P. Zajączkowski, Warszawa, Prószyński i S-ka, 2008, 589 ss.

Duda K., Szkice o prozie rosyjskiej XXI wieku. Ulicka, Szyszkin, Pielewin, Minajew,

Sienczyn, Kuricyn, Starobiniec..., Kraków, Księgarnia Akademicka, 2017, 266 ss.

Fast P., Realizm socjalistyczny, [w:] Historia literatury rosyjskiej XX wieku, red.

A. Drawicz, Warszawa, Wydawnictwo Naukowe PWN, 2002, ss. 329-370.

Galster B., Mickiewicz i Puszkin, [w:] Mickiewicz - Puszkin. Materiały źródłowe i bibliograficzne. Antologia, zebr. i oprac. J. Świdziński, wstępem opatrzył B. Galster, t. I, Mickiewicz o Puszkinie, Poznań, Wydawnictwo Poznańskiego Towarzystwa Przyjaciół Nauk, 1991, ss. 5-19. 
Geertz C., Interpretacja kultur. Wybrane eseje, thum. M.M. Piechaczek, Kraków, Wydawnictwo Uniwersytetu Jagiellońskiego, 2005, 533 ss.

Geertz C., Wiedza lokalna. Dalsze eseje z zakresu antropologii interpretatywnej, tłum. D. Wolska, Kraków, Wydawnictwo Uniwersytetu Jagiellońskiego, 2005, $251 \mathrm{ss}$.

Hyperborejczycy, thum. J. Sachse, [w:] P. Grimal, Stownik mitologii greckiej i rzymskiej, Wrocław, Zakład Narodowy im. Ossolińskich - Wydawnictwo, 1990, ss. $150-151$.

Łotman J., Kultura i eksplozja, tłum. i słowem wstępnym opatrzył B. Żyłko, Warszawa, Państwowy Instytut Wydawniczy, 1999, 261 ss.

Łotman J., Pamięć kultury, [w:] idem, Kultura, historia, literatura, wybór, tłum. i wstęp B. Żyłko, Gdańsk, Wydawnictwo Uniwersytetu Gdańskiego, 2017, ss. 133-143.

Łotman J., Uniwersum umysłu. Semiotyczna teoria kultury, tłum. i przedm. B. Żyłko, Gdańsk, Wydawnictwo Uniwersytetu Gdańskiego, 2008, 408 ss.

Mandelsztam O., Poezje, oprac. i wstęp R. Przybylski, Warszawa, Państwowy Instytut Wydawniczy, 1971, 168 ss.

Mickiewicz A., Dziadów części III Ustęp, [w:] idem, Dziady. Część III, posł. i przypisy

J. Wieczerska-Zabłocka, Wrocław, Zakład Narodowy im. Ossolińskich Wydawnictwo, 1984, ss. 171-212.

Mielichow A., Czerwony Syjon, tłum. N. Woroszylska, Warszawa, Wydawnictwo Sic!, 2007, 212 ss.

Moskwa Noir, red. J. Goumen, N. Smirnowa, tłum. E. Skórska, Warszawa, Claroscuro, 2011, 283 ss.

Petersburg Noir, red. J. Goumen, N. Smirnowa, thum. G. Szymczak, Warszawa, Claroscuro, 2015, 345 ss.

Piatigorski A., Łotman J., Tekst i funkcja, tłum. J. Faryno [w:] Semiotyka kultury, wybór i oprac. E. Janus i M.R. Mayenowa, przedm. S. Żółkiewski, Warszawa, Państwowy Instytut Wydawniczy, 1975, ss. 100-113.

Przybył-Sadowska E., Sadowski J., Urbanek D., Rosja. Przestrzeń, czas i znaki, Kraków, Wydawnictwo Libron - Filip Lohner, 2016, 351 ss.

Puszkin A., Jeździec Miedziany. Opowieść petersburska, [w:] Lutnia Puszkina. Utwory Aleksandra Puszkina wybrat i przettumaczyt Julian Tuwim, Wrocław, Zakład Narodowy im. Ossolińskich - Wydawnictwo, 2009, ss. 149-166.

Toporow W., Przestrzeń i tekst, [w:] idem, Przestrzeń i rzecz, thum. B. Żyłko, Kraków, Universitas, 2003, ss. 15-96.

Waginow K., Harpagoniada, thum. i posłowiem opatrzył A. Pomorski, Warszawa, Czytelnik, 2001, 256 ss.

Żyłko B., Semiotyka kultury, Gdańsk, słowo/obraz terytoria, 2009, 265 ss. 
315. Рассказы писателей Санкт-Петербурга, состав. сборника С. Кулешова и К. Грозная, Санкт-Петербург, Союз писателей Санкт-Петербурга / Издательский дом „Петрополис”, 2018, 290 ss.

Алексеев П., Глаголь жгли, „Литературная газета”, 16-22 мая 2018, nr 19 (6643), s. 21 .

Алексеева М., Петербург, я еще не хочу умирать, у меня телефонов твоих номера..., [w:] В Питере жить. От Двориовой до Садовой, от Гангутской до Шпалерной. Личные истории, zebrały Н. Соколовская, Е. Шубина, Москва, Издательство АСТ, 2017, ss. 277-286.

Арно С., Живодерня, Санкт-Петербург, Издательство „Северо-Запад”, 2005, 512 ss.

Арно С., Истории петербургских утопленниц, Санкт-Петербург, Издательство „Метропресс”, 2015, 256 ss.

Арно С., Смирительная рубашка для гениев. Роман-бред, Санкт-Петербург, Издательство Союза Писателей Санкт-Петербурга, 2012, 272 ss.

Арно С., Фредерик Рюйш и его дети, Санкт-Петербург, Союз Писателей Санкт-Петербурга, 2012, 496 ss.

Басова И., Возвращение, [w:] В Питере жить. От Двориовой до Садовой, от Гангутской до Шпалерной. Личные истории, zebrały Н. Соколовская, Е. Шубина, Москва, Издательство АCT, 2017, ss. 329-340.

Башмакова А., Дневник Хельги Лухан (урожденной Хайншаймер), „Аврора”, 2018 , nr 2, ss. 25-52.

Болдырев А.Н., Осадная запись (блокадный дневник), Санкт-Петербург, Европейский Дом, 1998, 368 ss.

Большая Топонимическая Энциклопедия Санкт-Петербурга, red. А.Г. Владимирович, Санкт-Петербург, Информационно-издательское агенство «ЛИК», 2013, 1136 pp.

Боярская Е., В Питере - жить!, [w:] В Питере жить. От Двориовой до Садовой, от ГангутскойдоШпалерной. Личные истории, zebrałyН. Соколовская, Е. Шубина, Москва, Издательство АСТ, 2017.

Быков Д., Елагин Остров, [w:] В Питере жить. От Двориовой до Садовой, от Гангутской до Шпалерной. Личные истории, zebrały Н. Соколовская, Е. Шубина, Москва, Издательство АСТ, 2017.

В Питере жить. От Двориовой до Садовой, от Гангутской до Шпалерной. Личные истории, zebrały Н. Соколовская, Е. Шубина, Москва, Издательство ACT, 2017, 528 ss.

Вагинов К.К., Гарпагониада, [w:] http://az.lib.ru/w/waginow_k_k/text_0040. shtml [dostęp: 21.05.2018].

Вагинов К К., Стихотворения и поэмы,, Москва, Директ-Медиа, 2014, 186 ss. 
Владимирский В., Сергей Арно: «Во всей нашей жизни мало здравого смысла», „Питерbook" 29.12.2012, [w:] http://krupaspb.ru/piterbook/fanclub/pb_fan_ column.html?nn=155\&ord=5\&sb=\&np=1 [dostęp: 27.05 .2018$]$.

Городницкий А., Василевский остров, [w:] В Питере жить. От Двориовой до Садовой, от Гангутской до Шпалерной. Личные истории, zebrały Н. Coколовская, Е. Шубина, Москва, Издательство АСТ, 2017, ss. 133-146.

Елисеев Н., Разорванный портрет, [w:] В Питере жить. От Двориовой до Садовой, от Гангутской до Шпалерной. Личные истории, zebrały Н. Соколовская, Е. Шубина, Москва, Издательство АСТ, 2017, ss. 21-61.

Жаднова Е. Н., Современные подходы к изучению проблемы петербургского текста, „Известия Саратовского университета. Новая серия. Серия Филология. Журналистика" 2013, t. 13, wyd. 4, ss. 70-74.

Колина Е., „Это Питер, детка”, [w:] В Питере жить. От Двориовой до Садовой, от Гангутской до Шпалерной. Личные истории, zebrały Н. Соколовская, Е. Шубина, Москва, Издательство АСТ, 2017, ss. 89-101.

Кондакова Д.Ю., Понятие «петербургский текст» в современной научной рецепции, „Вісник Харківського національного університету ім. В.Н. Каразіна", 2011, nr 936, wyd. 61, ss. 276-280.

Котов Д., Моя подьяческая история, [w:] В Питере жить. От Двориовой до Садовой, от Гангутской до Шпалерной. Личные истории, zebrały H. Coколовская, Е. Шубина, Москва, Издательство АСТ, 2017, ss. 233-239.

Коцюбинский Д., Вечность вместо жизни, [w:] В Питере жить. От Двориовой до Садовой, от Гангутской до Шиалерной. Личные истории, zebrały H. Coколовская, Е. Шубина, Москва, Издательство АСТ, 2017, ss. 241-252.

Крусанов П., Центр новый, незатопляемый, [w:] В Питере жить. От Дворцовой до Садовой, от Гангутской до Шпалерной. Личные истории, zebrały Н. Соколовская, Е. Шубина, Москва, Издательство АСТ, 2017, ss. 445-458. Лихачев Д.С., В блокадном Ленинграде, Москва, Алгоритм, 2017, 239 ss.

Лукин Е., Пространство русского духа, Санкт-Петербург, Союз художников, 2007, 158 ss.

Малышев В., Петербургские тайны. Занимательный исторический путеводитель, Санкт-Петербург, Союз писателей Петербурга, 2017, 304 ss.

Мандельштам О. Э., Сочинения в двух томах, t. 1: Стихотворения. Переводы, zebrała П.М. Нерлера, Москва, Художественная литература, 1990, 637 ss.

Мелихов А., Как бы нам остаться варварами?, [w:] В Питере жить. От Двориовой до Садовой, от Гангутской до Шпалерной. Личные истории, zebrały Н. Соколовская, Е. Шубина, Москва, Издательство АСТ, 2017, ss. 157-174. Мережковский Д. С., Петербургу быть пусту, [w:] http://az.lib.ru/m/merezhkowskij_d_s/text_0200.shtml [dostęp: 27.05.2018]. 
Обух А., Дикий янтарь. Рассказы, Санкт-Петербург, Издательство „АртЭкспресс", 2018, 132 ss.

Попов В., Мои места, [w:] В Питере жить. От Двориовой до Садовой, от Гангутской до Шиалерной. Личные истории, zebrały Н. Соколовская, Е. Шубина, Москва, Издательство АCT, 2017, ss. 357-365.

Тетерская Т.Н., В плену у блокадного детства. Петербургский роман, Санкт-Петербург, Издательство Союза Писателей Санкт-Петербурга, 2013, 272 ss. Толстая Т., Чужие сны, [w:] В Питере жить. От Двориовой до Садовой, от Гангутской до Шиалерной. Личные истории, zebrały Н. Соколовская, Е. Шубина, Москва, Издательство АСТ, 2017, ss. 11-18.

Топоров В. Н., Петербургский текст русской литературы, Санкт-Петербург, Искусство-СПБ, 2003, 616 ss.

Тюпа В., Коренная мифологема Петербургского текста, [w:] Сущеествует ли Петербургский текст?, pod red. В. М. Марковича, В. Шмида, Санкт-Петербург, Издательство Санкт-Петербургского университета, 2005, ss. 81-91.

Чупринин С., Русская литература сегодня. Жизнь по понятиям, Москва, Время, 2007, 768 ss.

\section{References}

315. Rasskazy pisatelei Sankt-Peterburga [315. Stories of the Writers of Saint Petersburg], S. Kuleshova, K. Groznaia (Eds.), Saint Petersburg, Soiuz Pisatelei Sankt-Peterburga / Izdatel'skii Dom "Petropolis", 2018, 290 pp.

Adamowicz A., Granin D., Księga blokady [A Book of the Blocade], trans. W. Bieńkowska, Warszawa, Państwowy Instytut Wydawniczy, 1988, 534 pp.

Alekseev P., Glagoly zhgli [Burning Verbs], "Literaturnaia gazeta" [Literary Newspaper] 16-22 maia 2018, no. 19 (6643), p. 21.

Alekseeva M., "Peterburg, ia eshche ne khochu umirat', u menia telefonov tvoikh nomera..." ["Petersburg, I Do Not Want to Die Yet, I Still Have Your Phone Numbers..."], [in:] V Pitere Zhit'. Ot Dvortsovoi do Sadovoi, ot Gangutskoi do Shpalernoi. Lichnye istorii [Living in Piter. From Dvortsovaya to Sadovaya, from Gangutskaya to Shpalernaya. Personal Stories], N. Sokolovskaia, E. Shubina (Eds.), Moscow, Izdatel'stvo AST, 2017, pp. 277-286.

Arno S., Frederik Riuish i ego deti [Frederik Ruysch and His Children], Saint Petersburg, Soiuz Pisatelei Sankt-Peterburga 2012, 496 pp.

Arno S., Istorii peterburgskikh utoplennits [The Stories of the St. Petersburg Drowned], Saint Petersburg, Izdatel'stvo "Metropress", 2015, 256 pp.

Arno S., Smiritel'naia rubashka dlia geniev. Roman-bred [A Straitjacket for Geniuses. 
Novel-nonsense], Saint Petersburg, Izdatel'stvo Soiuza Pisatelei Sankt-Peterburga, 2012, $272 \mathrm{pp}$.

Arno S., Zhivodernia [Knackery], Saint Petersburg, Izdatel'stvo "Severo-Zapad", 2005, 512 pp.

Bashmakova A., Dnevnik Khel'gi Lukhan (urozhdennoi Khainshaimer) [Diary of Helga Luhan (nee Heinsheimer)], "Avrora" ["Aurora"], 2018, no. 2, pp. 25-52. Basova I., Vozvrashchenie [A Return], [in:] V Pitere Zhit'. Ot Dvortsovoi do Sadovoi, ot Gangutskoi do Shpalernoi. Lichnye istorii [Living in Piter. From Dvortsovaya to Sadovaya, from Gangutskaya to Shpalernaya. Personal Stories], N. Sokolovskaia, E. Shubina (Eds.), Moscow, Izdatel'stvo AST, 2017, pp. 329-340.

Boiarskaia E., V Pitere - zhit'! [Living in Piter], [in:] V Pitere Zhit'. Ot Dvortsovoi do Sadovoi, ot Gangutskoi do Shpalernoi. Lichnye istorii [Living in Piter. From Dvortsovaya to Sadovaya, from Gangutskaya to Shpalernaya. Personal Stories], N. Sokolovskaia, E. Shubina (Eds.), Moscow, Izdatel'stvo AST, 2017, pp. 469476.

Boldyrev A.N., Osadnaia zapis' (blokadnyi dnevnik) [Siege Record (Blockade Diary)], Saint Petersburg, Evropeiskii Dom, 1998, 368 pp.

Bol'shaia Toponimicheskaia Entsiklopediia Sankt-Peterburga [The Great Toponymic Encyclopedia of St. Petersburg], A.G. Vladimirovich (Ed.), Saint Petersburg, Informatsionno-izdatel'skoe Agentstvo "LIK", 2013, 1136 pp.

Brążkiewicz B., 'Idioci rzqdzq światem'. Między fantastykq a realizmem - 'Powieść o miłości, ale też o idiotach i topielicach...' Siergieja Arny ["Idiots Rule the World." Between Fantasy and Reality - 'A Novel About Love, but Also About Idiots and Drowned Women...' by Sergey Arno],"Colloquia Litteraria Sedlcensia”, 2014, vol. XIV-II, pp. 19-26.

Brążkiewicz B., 'Smiritel'naja rubashka dlja geniev' Sergeja Arno ili vopros o literaturnom krizise ['A Straitjacket for Geniuses' by Sergey Arno or the Question of Literary Crisis], "Kultura Słowian. Rocznik Komisji Kultury Słowian PAU" [Proceedings of the Commission on the Culture of the Slavs] 2017, vol. XIII, pp. 235-244.

Brążkiewicz B., Ku tajemnicy życia wiecznego. Piotr I i Frederik Ruysch w historyczno-fantastycznej powieści S. Arno 'Frederik Rjujsh i ego deti' [Toward the Mystery of Eternal Life. Peter the Great and Frederik Ruysch in S. Arno's Historical Fantasy 'Frederik Rjujsh i ego deti'], [in:] Sacrum świata wschodniego izachodniego w kulturze stowiańszczyzny. Musica Antiqua Europae Orientalis XVII, Acta Slavica [Sacrum of the Eastern and Western World in the Slavic Culture. Musica Antiqua Europae Orientalis XVII, Acta Slavica], Bydgoszcz, Filharmonia Pomorska im. Ignacego Paderewskiego w Bydgoszczy, 2014, pp. 441449. 
Brążkiewicz B., Mroczny Petersburg. Proza Siergieja Arno [Dark Petersburg. Sergey Arno's Prose], [in:] Światto i ciemność w literaturze, kulturze i sztuce: od antyku do współczesności [Light and Darkness in Literature, Culture and Art: From Atiquity to Modern Times], D. Szymonik, E. Kozak, A. Pogoda-Kołodziejak (Eds.), Siedlce, Instytut Neofilologii i Badań Interdyscyplinarnych Uniwersytet Przyrodniczo-Humanistyczny w Siedlcach, Instytut Kultury Regionalnej i Badań Interdyscyplinarnych im. Franciszka Karpińskiego. Stowarzyszenie, 2015, pp. 103-111.

Brążkiewicz B., Uprawdopodobnienie fikcji w powieści Siergieja Arno 'Smiritel'naya rubashka dlya geniyev' [Making Fiction Plausible in Sergey Arno's Novel 'Smiritel'naya Rubashka dlya Geniyev'], "Conversatoria Litteraria” [Literary Conversations] 2016, X, pp. 263-274.

Bukowski W., I powraca wiatr... [To Build a Castle: My Life as a Dissenter], trans. A. Mietkowski, Gdynia, Petit, 1990, 316 pp.

Bykov D., Elagin Ostrov [Elagin Island], [in:] V Pitere Zhit'. Ot Dvortsovoi do Sadovoi, ot Gangutskoi do Shpalernoi. Lichnye istorii [Living in Piter. From Dvortsovaya to Sadovaya, from Gangutskaya to Shpalernaya. Personal Stories], N. Sokolovskaia, E. Shubina (Eds.), Moscow, Izdatel'stvo AST, 2017, pp. 175-203.

Chuprinin S., Russkaia literatura segodnia. Zhizn'po poniatiiam [Russian Literature Today. Life According to Concepts], Moscow, Vremia, 2007, 768 pp.

Czerwiński M., Archiwum znaków - semiotyka pamięci kulturowej [Archive of Signs: The Semiotics of Cultural Memory ], "Tekst i dyskurs - Text Und Diskurs" [Text and Discourse - Text und Diskurs] 2014, no. 7, pp. 31-48.

Dostojewski F., Młodzik [The Adolescent], trans. J. Polecki, Białystok, Instytut Wydawniczy Kreator, 2002, 557 pp.

Dostojewski F., Zbrodnia i kara. Powiesśc w sześciu częściach z epilogiem [Crime and Punishment. A Novel in Six Parts with an Epilogue], trans. J.P. Zajączkowski, Warszawa, Prószyński i S-ka, 2008, 589 pp.

Duda K., Szkice o prozie rosyjskiej XXI wieku. Ulicka, Szyszkin, Pielewin, Minajew, Sienczyn, Kuricyn, Starobiniec... [Sketches on the Russian Prose of the $21^{\text {st }}$ Century. Ulitskaya, Shishkin, Pelevin, Mineav, Sentchin, Kuritsyn, Starobinets...], Kraków, Księgarnia Akademicka, 2017, 266 pp.

Eliseev N., Razorvannyi portret [The Torn Portrait], [in:] V Pitere Zhit'. Ot Dvortsovoi do Sadovoi, ot Gangutskoi do Shpalernoi. Lichnye istorii [Living in Piter. From Dvortsovaya to Sadovaya, from Gangutskaya to Shpalernaya. Personal Stories], N. Sokolovskaia, E. Shubina (Eds.), Moscow, Izdatel'stvo AST, 2017, pp. 21-61. Fast P., Realizm socjalistyczny [Socialist Realism], [in:] Historia literatury rosyjskiej $X X$ wieku [History of $20^{\text {th }}$ Century Russian Literature], A. Drawicz (Ed.), Warszawa, Wydawnictwo Naukowe PWN, 2002, pp. 329-370. 
Galster B., Mickiewicz i Puszkin [Mickiewicz and Pushkin], [in:] Mickiewicz Puszkin. Materiatyźródłowe i bibliograficzne. Antologia [Mickiewicz-Pushkin. Sources and Bibliographic Materials. An Anthology], collected and developed by J. Świdziński, with an introduction by B. Galster, vol. I, Mickiewicz o Puszkinie [Mickiewicz about Pushkin], Poznań, Wydawnictwo Poznańskiego Towarzystwa Przyjaciół Nauk, 1991, pp. 5-19.

Geertz C., Interpretacja kultur. Wybrane eseje [The Interpretation of Cultures.

Selected Essays], trans. M.M. Piechaczek, Kraków, Wydawnictwo Uniwersytetu Jagiellońskiego, 2005, 533 pp.

Geertz C., Wiedza lokalna. Dalsze eseje z zakresu antropologii interpretatywnej [Local Knowledge. Further Essays in Interpretive Anthropology], trans. D. Wolska, Wydawnictwo Uniwersytetu Jagiellońskiego, Kraków 2005, 251 pp.

Gorodnitskii A., Vasilevskii ostrov [Vasilievsky Island], [in:] V Pitere Zhit'. Ot Dvortsovoi do Sadovoi, ot Gangutskoi do Shpalernoi. Lichnye istorii [Living in Piter. From Dvortsovaya to Sadovaya, from Gangutskaya to Shpalernaya. Personal Stories], N. Sokolovskaia, E. Shubina (Eds.), Moscow, Izdatel'stvo AST, 2017, pp. 133-146.

Hyperborejczycy [Hyperboreans], trans. J. Sachse [in:] P. Grimal, Stownik mitologii greckiej i rzymskiej [Dictionary of Greek and Roman Mythology], Wrocław, Zakład Narodowy im. Ossolińskich - Wydawnictwo, 1990, pp. 150-151.

Kolina E., "Eto Piter, detka" ["This is Piter, baby"], [in:] V Pitere Zhit'. Ot Dvortsovoi do Sadovoi, ot Gangutskoi do Shpalernoi. Lichnye istorii [Living in Piter. From Dvortsovaya to Sadovaya, from Gangutskaya to Shpalernaya. Personal Stories], N. Sokolovskaia, E. Shubina (Eds.), Moscow, Izdatel'stvo AST, 2017, pp. 89-101.

Kondakova D. Iu., Poniatie «peterburgskii tekst» v sovremennoi nauchnoi retseptsii [Scientific Reception of the Concept of "Petersburg Text" in Modern Literary Studies], "Visnik Kharkivs'kogo natsional'nogo universitetu im. V.N. Karazina" [Journal of V. N. Karazin Kharkiv National University] 2011, no. 936, vol. 61, pp. 276-280.

Kotov D., Moia pod'iacheskaia istoriia [My Clerk Story], [in:] V Pitere Zhit'. Ot Dvortsovoi do Sadovoi, ot Gangutskoi do Shpalernoi. Lichnye istorii [Living in Piter. From Dvortsovaya to Sadovaya, from Gangutskaya to Shpalernaya. Personal Stories], N. Sokolovskaia, E. Shubina (Eds.), Moscow, Izdatel'stvo AST, 2017, pp. 233-239.

Kotsiubinskii D., Vechnost'vmesto zhizni [Eternity Instead of Life], [in:] V Pitere Zhit'. Ot Dvortsovoi do Sadovoi, ot Gangutskoi do Shpalernoi. Lichnye istorii [Living in Piter. From Dvortsovaya to Sadovaya, from Gangutskaya to Shpalernaya. 
Personal Stories], N. Sokolovskaia, E. Shubina (Eds.), Moscow, Izdatel'stvo AST, 2017, pp. 241-252.

Krusanov P., Tsentr novyi, nezatopliaemyi [New Center, Flood-Free], [in:] V Pitere Zhit'. Ot Dvortsovoi do Sadovoi, ot Gangutskoi do Shpalernoi. Lichnye istorii [Living in Piter. From Dvortsovaya to Sadovaya, from Gangutskaya to Shpalernaya. Personal Stories], N. Sokolovskaia, E. Shubina (Eds.), Moscow, Izdatel'stvo AST, 2017, pp. 445-458.

Likhachev D. S., V blokadnom Leningrade [In Besieged Leningrad], Moscow, Algoritm, 2017, 239 pp.

Łotman J., Kultura i eksplozja [Culture and Explosion], trans. and introduction by B. Żyłko, Warszawa, Państwowy Instytut Wydawniczy, 1999, 261 pp.

Łotman J., Pamięć kultury [Memory of Culture], [in:] idem, Kultura, historia, literatura, [Culture, History, Literature], selection, trans. and introduction by B. Żyłko, Gdańsk, Wydawnictwo Uniwersytetu Gdańskiego, 2017, pp. 133-143.

Łotman J., Uniwersum umystu. Semiotyczna teoria kultury [Universe of the Mind. A Semiotic Theory of Culture], trans. and introduction by B. Żyłko, Gdańsk, Wydawnictwo Uniwersytetu Gdańskiego, 2008, 408 pp.

Lukin E., Prostranstvo russkogo dukha [The Space of the Russian Spirit], Saint Petersburg, Soiuz Khudozhnikov, 2007, 158 pp.

Malyshev V., Peterburgskietainy. Zanimatel'nyi istoricheskiiputevoditel'[Petersburg Secrets. An Entertaining Historical Guide], Saint Petersburg, Soiuz Pisatelei Peterburga, 2017, 304 pp.

Mandel'shtam O. Je., Sochinenija v dvuh tomah, t. 1: Stihotvorenija. Perevody [Works in Two Volumes, vol. 1: Poems. Translations], P.M. Nerler (Ed.), Moscow, Hudozhestvennaja literatura, 1990, $637 \mathrm{pp}$.

Mandelsztam O., Poezje [Poems], ed. and introduction by R. Przybylski, Warszawa, Państwowy Instytut Wydawniczy, 1971, 168 pp.

Melikhov A., Kak by nam ostat 'sia varvarami? [How Would We Remain Barbarians?], [in:] V Pitere Zhit'. Ot Dvortsovoi do Sadovoi, ot Gangutskoi do Shpalernoi. Lichnye istorii [Living in Piter. From Dvortsovaya to Sadovaya, from Gangutskaya to Shpalernaya. Personal Stories], N. Sokolovskaia, E. Shubina (Eds.), Moscow, Izdatel'stvo AST, 2017, pp. 157-174.

Merezhkovskii D.S., Peterburgu byt'pustu [Petersburg Will Stand Empty], Available at: http://az.lib.ru/m/merezhkowskij_d_s/text_0200.shtml [accessed 27.05.2018]. Mickiewicz A., Dziadów części III Ustęp [The Passage of Forefathers' Eve Part III], [in:] idem, Dziady. Część III [Forefathers' Eve Part III], afterword and footnotes by J. Wieczerska-Zabłocka, Wrocław, Zakład Narodowy im. Ossolińskich Wydawnictwo, 1984, pp. 171-212. 
Mielichow A., Czerwony Syjon [Red Zion], trans. N. Woroszylska, Warszawa, Wydawnictwo Sic!, 2007, 212 pp.

Moskwa Noir [Moscow Noir], J. Goumen, N. Smirnowa (Eds.), trans. E. Skórska, Warszawa, Claroscuro, 2011, 283 pp.

Obukh A., Dikii iantar'. Rasskazy [Wild Amber. Short Stories], Saint Petersburg, Izdatel'stvo "Art-Ekspress", 2018, 132 pp.

Petersburg Noir [Petersburg Noir], J. Goumen, N. Smirnowa (Eds.), trans. G. Szymczak, Warszawa, Claroscuro, 2015, 345 pp.

Piatigorski A., Łotman J., Tekst i funkcja [Text and Function], trans. J. Faryno, [in:] Semiotyka kultury [Semiotics of Culture], E. Janus, M.R. Mayenowa (Eds.), introduction by S. Żółkiewski, Warszawa, Państwowy Instytut Wydawniczy, 1975, pp. 100-113.

Popov V., Moi mesta [My Places], [in:] V Pitere Zhit'. Ot Dvortsovoi do Sadovoi, ot Gangutskoi do Shpalernoi. Lichnye istorii [Living in Piter. From Dvortsovaya to Sadovaya, from Gangutskaya to Shpalernaya. Personal Stories], N. Sokolovskaia, E. Shubina (Eds.), Moscow, Izdatel'stvo AST, 2017, pp. 357-365.

Przybył-Sadowska E., Sadowski J., Urbanek D., Rosja. Przestrzeń, czas i znaki [Russia. Space, Time and Signs], Kraków, Wydawnictwo Libron - Filip Lohner, 2016, $351 \mathrm{pp}$.

Puszkin A., Jeździec Miedziany. Opowieść petersburska [The Bronze Horseman. A Petersburg Tale], [in:] Lutnia Puszkina. Utwory Aleksandra Puszkina wybrat i przettumaczyt Julian Tuwim [Pushkin's Lute. Selected poems, translated and edited by J. Tuwim], Wrocław, Zakład Narodowy im. Ossolińskich Wydawnictwo, 2009, pp. 149-166.

Teterskaia T.N., V plenu u blokadnogo detstva. Peterburgskii Roman [In Captivity of Besieged Childhood. Petersburg Novel], Saint Petersburg, Izdatel'stvo Soiuza Pisatelei Sankt-Peterburga, 2013, 272 pp.

Tiupa V., Korennaia mifologema Peterburgskogo teksta [The Root Mythologem of Petersburg Text], [in:] Sushchestvuet li Peterburgskii tekst? [Does Petersburg Text exist?], V. M. Markovich, V. Shmid (Eds.), Saint Petersburg, Izdatel'stvo Sankt-Peterburgskogo Universiteta, 2005, pp. 81-91.

Tolstaia T., Chuzhie sny [Others' Dreams], [in:] V Pitere Zhit'. Ot Dvortsovoi do Sadovoi, ot Gangutskoi do Shpalernoi. Lichnye istorii [Living in Piter. From Dvortsovaya to Sadovaya, from Gangutskaya to Shpalernaya. Personal Stories], N. Sokolovskaia, E. Shubina (Eds.), Moscow, Izdatel'stvo AST, 2017, pp. 11-18. Toporov V.N., Peterburgskii tekst russkoi literatury [Petersburg Text of Russian Literature], Saint Petersburg, Iskusstvo-SPB, 2003, 616 pp.

Toporow W., Przestrzeń i tekst [Space and Text], [in:] idem, Przestrzeń i rzecz [Space and Thing], trans. B. Żyłko, Kraków, Universitas, 2003, pp. 15-96. 
V Pitere Zhit'. Ot Dvortsovoi do Sadovoi, ot Gangutskoi do Shpalernoi. Lichnye istorii [Living in Piter. From Dvortsovaya to Sadovaya, from Gangutskaya to Shpalernaya. Personal Stories], N. Sokolovskaia, E. Shubina (Eds.), Moscow, Izdatel'stvo AST, 2017, 528 pp.

Vaginov K.K., Garpagoniada [Harpagoniana], Available at: http://az.lib.ru/w/waginow_k_k/text_0040.shtml [accessed: 21.05.2018].

Vaginov K.K., Stikhotvoreniia i poemy [Poetry and poems], Moscow, Direkt-Media, 2014, 186 pp.

Vladimirskii V., Sergei Arno: "Vo vsei nashei zhizni malo zdravogo smysla» [Sergei Arno: "There Is Little Common Sense in Our Whole Life"], "Piterbook" [Piterbook] 29.12.2012, Available at: http://krupaspb.ru/piterbook/fanclub/pb_ fan_column.html?nn=155\&ord=5\&sb=\&np=1 [accessed: 21.05 .2018$]$.

Waginow K., Harpagoniada [Harpagoniana], trans. and afterword A. Pomorski, Warszawa, Czytelnik, 2001, 256 pp.

Zhadnova E. N., Sovremennye podkhody k izucheniiu problemy peterburgskogo teksta [Contemporary Approaches to the Research of the Problem of Petersburg's Text of the Russian Literature], "Izvestiia Saratovskogo universiteta. Novaia seriia. Seriia Filologiia. Zhurnalistika" [News of Saratov University. News Series. Philology Series. Journalism], 2013, vol. 13, no. 4, pp. 70-74

Żyłko B., Semiotyka kultury [Semiotics of Culture], Gdańsk, słowo/obraz terytoria, 2009, 265 pp. 
